Meta

Journal des traducteurs

Translators' Journal

\title{
From Harry to Garri
}

Strategies for the Transfer of Culture and Ideology in Russian
Translations of Two English Fantasy Stories

\section{Judith Inggs}

Volume 48, numéro 1-2, mai 2003

URI : https://id.erudit.org/iderudit/006975ar

DOI : https://doi.org/10.7202/006975ar

Aller au sommaire du numéro

\section{Éditeur(s)}

Les Presses de l’Université de Montréal

\section{ISSN}

0026-0452 (imprimé)

1492-1421 (numérique)

Découvrir la revue

\section{Citer cet article}

Inggs, J. (2003). From Harry to Garri: Strategies for the Transfer of Culture and Ideology in Russian Translations of Two English Fantasy Stories. Meta, 48(1-2), 285-297. https://doi.org/10.7202/006975ar

\section{Résumé de l'article}

Cet article porte sur l'analyse de deux exemples particuliers d'histoires fantastiques et sur leur traduction en russe. Ces deux histoires sont Le lion, la sorcière et l'armoire (Lewis 1950), histoire fantastique anglaise classique, et Harry Potter et la pierre du philosophe (Rowling 1997), mariage moderne d'histoire fantastique et d'histoire traditionnelle anglaise. Notre analyse montre que l'approche utilisée dans ces traductions n'est pas uniforme. La simplification est utilisée comme stratégie de traduction dans Le lion, la sorcière et l'armoire, mais il y a aussi plusieurs confusions en ce qui concerne la traduction de termes culturels dans Harry Potter et la pierre du philosophe. En général, les traducteurs n'ont pas cherché à situer les histoires dans un contexte russe, mais ont gardé de façon intacte la toile de fond culturelle et les valeurs morales du texte original. Une étude sur la réception de ces textes par les jeunes lecteurs fournirait des informations précieuses sur l'échec ou la réussite de ces traductions. (c) Les Presses de l’Université de Montréal,
Ce document est protégé par la loi sur le droit d'auteur. L’utilisation des services d'Érudit (y compris la reproduction) est assujettie à sa politique d'utilisation que vous pouvez consulter en ligne.

https://apropos.erudit.org/fr/usagers/politique-dutilisation/ 


\title{
From Harry to Garri: Strategies for the Transfer of Culture and Ideology in Russian Translations of Two English Fantasy Stories
}

\author{
JUDITH INGGS \\ University of the Witwatersrand, Johannesburg, South Africa \\ jinggs@languages.wits.ac.za
}

\begin{abstract}
RÉSUMÉ
Cet article porte sur l'analyse de deux exemples particuliers d'histoires fantastiques et sur leur traduction en russe. Ces deux histoires sont Le lion, la sorcière et l'armoire (Lewis 1950), histoire fantastique anglaise classique, et Harry Potter et la pierre du philosophe (Rowling 1997), mariage moderne d'histoire fantastique et d'histoire traditionnelle anglaise. Notre analyse montre que l'approche utilisée dans ces traductions n'est pas uniforme. La simplification est utilisée comme stratégie de traduction dans Le lion, la sorcière et l'armoire, mais il y a aussi plusieurs confusions en ce qui concerne la traduction de termes culturels dans Harry Potter et la pierre du philosophe. En général, les traducteurs n'ont pas cherché à situer les histoires dans un contexte russe, mais ont gardé de façon intacte la toile de fond culturelle et les valeurs morales du texte original. Une étude sur la réception de ces textes par les jeunes lecteurs fournirait des informations précieuses sur l'échec ou la réussite de ces traductions.
\end{abstract}

\begin{abstract}
This article focuses specifically on two examples of fantasy stories and their translations into Russian: The Lion, the Witch, and the Wardrobe (Lewis 1950), a classic English fantasy story, and Harry Potter and the Philosopher's Stone (Rowling 1997), a modern blending of fantasy with the traditional English school story. The analysis shows that the approach to translation is largely random. In the translations of The Lion, the Witch and the Wardrobe, there is some evidence of simplification as a strategy, and some confusion over the appropriate translation of cultural items in the translations of Harry Potter and the Philosopher's Stone. Generally, however, the translators are shown not to have attempted to situate the stories in a Russian context, and have retained intact both the cultural backdrop and the moral values put forward in the works. A study of the reception of such works by young readers would provide valuable information about the success or failure of the translations discussed in this article.
\end{abstract}

\section{MOTS-CLÉS/KEYWORDS}

children's literature, fantasy, culture, ideology, identity

Issues of culture and ideology are central to any analysis of literature. They are particularly important in translated children's literature because of the dual role such literature plays both in shaping the child's cultural identity and world-view, and in broadening the child's knowledge and understanding of other cultures. The specific case of the translation of English children's literature into Russian is especially interesting given the very different cultural context of the two literatures, and the changes in translation practice that have taken place in Russia since the dissolution of the Soviet Union. This article focuses specifically on two examples of fantasy stories and 
their translations into Russian: The Lion, the Witch, and the Wardrobe (Lewis 1950), a classic English fantasy story, and Harry Potter and the Philosopher's Stone (Rowling 1997), a modern blending of fantasy with the traditional English school story. These stories were chosen for their strong cultural and ideological content, as both are firmly rooted in an English context. Certain features of the works are examined in different translations, to investigate to what extent translators play a mediating role in order to make the works more accessible to a young Russian reader.

All literary works reflect the writer's personal ideology, either consciously or unconsciously. In the field of children's literature, ideological content has been the focus of a number of critical works (for example, Dixon 1977, 1978, and Sutherland 1985). One of the central issues is how ideology is embedded in the text, and which strategies the writer adopts in order to put forward a particular value system. Sutherland identifies three categories which he calls the politics of advocacy, attack or assent (1985:151). The first involves an active, motivated promotion of values, while the second makes use of irony and satire to mount a direct attack on an opposing ideology. The third is the most insidious, and the most interesting from the point of view of translation, as it affirms ideologies prevalent in a particular society, by inconspicuously reflecting the implied reader's beliefs and assumptions. Once a text has been translated and transferred into another culture with a different ideological basis, the new reader may no longer share these assumptions. Readers may then feel alienated from the text, or they may be consciously aware, in a way that source text readers are not, that they are being manipulated into a particular subject position. In both cases, the target culture reader may regard the text in a less favourable light, because of the mismatch between source and target culture values and assumptions.

Recognising the general disparity between the two readerships, the translator of children's books often feels justified in taking liberties with the source text in order to move the text closer to the target language reader. Such action is often further justified by the fact that children's literature generally holds a peripheral position in relation to mainstream literature. Shavit demonstrated in Poetics of Children's Literature (1986: 121-128) that translators of children's literature often adapt the text to fit in with existing models in the target system, write abridged versions of the original text, simplify complex narrative structures or content, or, most significantly, adjust the text for ideological and didactic reasons. Such adaptations and adjustments to the plot, characterisation and language provide considerable insight into the target language ideology, revealing a society's attitude to childhood and the content of children's literature. At the same time, the role of translated children's literature in furthering understanding and tolerance of other cultures would be defeated if the translator attempted to remove all those elements specific to the source language culture.

If it is agreed that the primary requirement of translations of children's books should be "the ability to arouse in the reader the same feelings, thoughts and associations experienced by readers of the source text" (Nikolajeva 1996: 28), then deviations from the source text in an attempt to meet this criterion are to be expected. For example, Boris Zakhoder, the well-known Russian children's writer and translator, in his translation of Alice in Wonderland, replaces parodies of English rhymes with parodies of Russian ones. ${ }^{1}$ By choosing such a strategy, the translator manipulates the culturally significant elements of the source and target cultures, in order to ensure 
that the text is as meaningful and accessible to the target text reader as it was to the source text reader. If the translator chooses to produce a text orientated more strongly towards the source text, then even seemingly simple elements, such as food and clothing, along with more complex elements, such as value systems and relations between characters, may take on a significance that may be confusing to the reader. This is one reason that textual and lexical accuracy is not always the overriding aim of the translator.

When examining translations from English to Russian it is important to note that the context of Russian children's literature during most of the twentieth century was very different from that of English children's literature. In Soviet ideology, the pedagogical role of children's literature was paramount (see Shneidman, 1973). Further, in order to instil a communist ideology, reality had to be reflected in a positive light, and doubts and uncertainties in the minds of characters, or excessive introspection, were discouraged. This prerequisite governed much of the content of literature for children during the greater part of the twentieth century, and stories about the Revolution, the Civil War, and the Second World War feature prominently (Aspatore 1986). Works in translation were generally selected based on ideological content, rather than literary value, so that a number of classic foreign-language works for children remained untranslated. Many classic English fantasy works have long been familiar to Russian-speaking children, including Alice in Wonderland, ${ }^{2}$ Peter Pan, and Mary Poppins, which have all been available in Russian translation for many years. ${ }^{3}$ However, other works have been notably absent, and by the end of the 1980 s, both writers and educators were expressing considerable dissatisfaction with such omissions. A report in the journal Detskaya Literatura in August 1989, listed the thirty authors dominating translations between 1918 and 1978. This list includes writers such as Charles Dickens, Rudyard Kipling, Jack London and Mark Twain. But the report also points to the lack of Russian translations of such varied works as E. B. White's classic, Charlotte's Web, the stories of Beatrix Potter, and even the works of Enid Blyton and the Tarzan series (Vol'pe 1989: 45). ${ }^{4}$ Other omissions included the works of E. Nesbit, from the end of the nineteenth century, and works from the latter half of the twentieth century, for example, C.S. Lewis and Roald Dahl. The political changes of 1990 saw a flurry of new translations, including Dahl's Charlie and the Chocolate Factory, which was published in Pioneer in August and September 1991, a trend that has continued over the last ten to twelve years.

It would therefore be reasonable to suppose that the late arrival of the Narnia chronicles in mainstream translated Russian children's literature is a result of their strong Christian content. The earliest translation of The Lion, the Witch and the Wardrobe, by G. Ostrovskaya, appeared in 1978, but was not widely available during the 1980s. It was reprinted in an eight volume series of Lewis's works in 1999 and is now extremely well known. An alternative translation, by L. Lyakhova, was published in 1992 by one of the many new publishing houses that mushroomed at that time. Translations of the other books in the series also appeared during the 1990s, often on websites devoted to C.S. Lewis, occasionally with no named translator. ${ }^{5}$

In the West, the books are primarily regarded as works of fantasy. The prefaces to the works published in the Puffin series of paperbacks describe the stories as magical adventures, about the magical and mystical land of Narnia, suitable for children aged from nine to twelve. In Russia, they appear to have been appropriated 
primarily as works of Christian literature. The books are viewed as having an educational role, reinforcing religious beliefs and instilling Christian morality into contemporary children (Kuraev, 2001). This attitude towards the books is very much in keeping with the traditional Russian view of children's literature as a pedagogical tool.

In Lewis's work, the implied reader clearly belongs to an English culture and to the English middle-class of the 1950s. It is true that the work rests on a prior knowledge of the Christian story of the creation, and a familiarity with the story of the crucifixion and resurrection. These elements are retained intact in both translations, with no intervention from the translators. The readiness with which the new target text readers would recognise the allusions to these stories from the Bible would depend very much on their religious background and prior experience of Christianity. This may also be true of contemporary English readers who do not come from a Christian background. On another level, however, the Narnia chronicles are also very much rooted in English culture.

When dealing with cultural elements and the landscape in which the story is set, both translations examined here adopt strategies of simplification or clarification. At the beginning of the novel, the reader learns that the children have been sent to the country because of the war-time air-raids on London. In order to ensure understanding, Lyakhova, for example, explains that London was frequently bombed by German airplanes during the war (1992: 141). Lewis locates the professor's house "in the heart of the country," ten miles from the nearest railway station and two miles from the nearest post-office, emphasising its isolation in rural England. Both translations relocate the house to the "centre of England" (not necessarily true), while the railway station disappears altogether. Lyakhova also omits the post-office, and Ostrovskaya moves the post-office to the distance of the railway station. Perhaps two miles is relatively close in the mind of a Russian child, given the very different scale of space in Russia compared to England.

Both translators on occasion use a more general word when faced with specific lexical items, especially if of cultural significance. For example, when describing the stream and the forest around the house, Lewis refers to the garden in which the house is situated. Lyakhova rather places the house in the middle of a park, probably because one would not imagine a house having such a large garden in a Russian context. Ostrovskaya uses a similar strategy in other instances, and reduces the reference to "lying in the heather" (29) to valyalis' na trave (lying around in the grass) (1999: 23). Similarly, when Edmund notices that there is "not even a robin or a squirrel among the trees" (1976: 32), Ostrovskaya uses the superordinate "bird" instead of "robin" (1999: 24), a shift that does not occur in the other translation. However, this strategy is not consistent, and in the detailed description of the onset of spring at the end of Chapter 11, both translators refer to the same trees and flowers as in the original, with one exception. Instead of referring to a laburnum, Oranskii chooses to substitute akatsia (acacia), although both have yellow flowers (1999: 78).

Strategies of simplification or even justification are also evident in the translation of social elements. For example, the liberal laws the children make while they are kings and queens are intended to appeal to both children and parents - saving trees from being cut down, liberating young dwarfs and satyrs from being sent to school and encouraging people to "live and let live" (166). Neither translator seems happy with the idea of the removal of compulsory education. Ostrovskaya changes the 
reference to "dopol'nitel'nye zanyatie $v$ shkole" (additional lessons at school), a less radical notion in a society in which education is treated with considerable reverence by parents and educators (115), while Lyakhova adds the adjective "compulsory" to avoid the suggestion of no school at all - "obyazatel'noe poseshchenie shkoly" (258).

The significant role of food in children's literature in general, and in The Lion, the Witch and the Wardrobe in particular, has been discussed in detail by Nikolajeva (2000:128-130). Food is often used in children's literature as a means of gaining entry to the other world, as a symbol of community and shared union, and as a central symbol of security. This applies to both Lewis's work and to Harry Potter and the Philosopher's Stone. The manifestation of these functions in terms of food items is also strongly rooted in the source language cultural system. As these passages carry strong cultural significations, the translators' strategies are important in ensuring that the ritual functions in a similar way in the new cultural context. It is the role or function fulfilled by the food that is significant, rather than the specific nature of the items.

Lucy is initially enticed into the Faun's home by the offer of tea. He asks "how would it be if you came and had tea with me?" and, when she hesitates, he tempts her further by promising "there'll be a roaring fire - and toast - and sardines - and cake" (p. 17). The preoccupation with tinned sardines at the time is typical of England in the 1950s (Enid Blyton's famous midnight feasts always included the unlikely combination of tinned sardines and evaporated milk), but they do not go particularly well with cake. There being no equivalent in Russian to the very English meal designated "tea," both translators have the Faun inviting Lucy to drink a cup of tea (vypit' chashechku chaiu), but the food on offer is similar in all three texts. The ritual nature of "taking tea" and the importance of the scene as a means through which Lucy and the Faun establish a sense of union and loyalty are simplified to some extent by both translators, but especially by Ostrovskaya. Lewis's style in this passage emphasises both the abundance of food and the length of the meal, reinforcing the bond between the Faun and Lucy. This is partially achieved by means of repetition:

And really it was a wonderful tea. There was a nice brown egg, lightly boiled, for each of them, and then sardines on toast, and then buttered toast, and then toast with honey, and then a sugar-topped cake. (pp. 19-20)

"And then" is a typical device to indicate a sequence of events, and one often used by young children in their own story-telling. Although Ostrovskaya also uses and, the absence of then reduces the sequential nature of the meal, and the passage becomes descriptive rather than narrative:

$$
\begin{aligned}
& \text { Чего только не было на столе! И яйца всмятку - по яйцу на } \\
& \text { каждого из них, - и поджаренный хлеб, и сардины, и масло, и } \\
& \text { мед, и облитый сахарной глазурью пирог. (ст.16) }
\end{aligned}
$$

What wasn't on the table! Soft-boiled eggs - one egg for each of them - and toasted bread, and sardines, and butter, and honey, and a sugar-glazed pie. ${ }^{6}$

The later translation, in keeping with its generally more literal - and occasionally therefore stilted - approach, keeps to the sequential structure: 
Чаепитие в самом деле получилось чудесное. Были поданы
хорошенькие яички в коричневой скорлупе, сваренные всмятку,

по одному на каждого, сардинки на ломтиках поджаренного

хлеба, потом - поджаренный хлеб с маслом, потом

The tea really did turn out to be excellent. There were nice little eggs in a brown shell, lightly boiled, one for each of them, sardines on slices of toasted bread, then - toasted bread with butter, then toasted bread with honey, then little pastries with sugar toppings.

Food is also the means by which Edmund is enticed by the White Witch to betray his brother and sisters. Eating the enchanted food brands him a traitor, and binds him to the Witch's service. He is first given a hot drink, which he does not recognise, but which warms him "right down to his toes" (36) and when asked what he would like best to eat, he chooses Turkish Delight. This is regarded as a sweet for special occasions in England, and would have been particularly scarce during the Second World War. In Russia it is one kind of vostochniye sladosti (Eastern sweets), specifically known as rakhat-lukum, the term used by Ostrovskaya, while Lyakhova chooses turetskie sladosti (Turkish sweets), a rather awkward, and certainly uncommon, term. The significance of the food however lies in its function and connotation within the source language culture - rather exotic and luxurious in English. Whoever eats this food will always crave more, even to point of eating himself to death. Ostrovskaya again tones down the text, telling the reader that he will eat and eat and eat because it is so delicious (28).

In the ideological and religious/magical content of the text, especially in passages dealing with the Deep Magic that governs the land of Narnia, simplification strategies are evident. When Aslan pushes the White Witch to explain why she has a right to slay Edmund because of his treachery, Ostrovskaya changes, and even omits, certain elements in the original. The original reads:

Tell you what is written in letters deep, as a spear is long on the fire-stones of the Secret Hill? Tell you what is engraved on the sceptre of the Emperor-Over-Sea? You at least know the Magic which the Emperor put into Narnia at the very beginning. (p. 128)

All references to the Emperor are removed:

поджаренный хлеб с медом, потом пирожные с сахарными

головками. (ст. 150)

Tell you, what is engraved, as if with the strokes of a spear, on the sacrificial stone of the

Hidden Hill? You know as well as I do the Magic, which Narnia has been subject to since long long ago.

while Lyakhova chooses more explicit and literal structures and retains the important references to the Emperor:

Рассказать, что высечено, словно ударами копья, на жертвенном

камне Заповедного Холма? Вы не хуже мне знаете Магию,

которой подвластна Нарния с давных времен... (ст. 90) 
Do I have to tell you... what is cut into the fiery stone in the Secret Hill - in letters each of which is as deep as the shaft of a spear? What is engraved on the sceptre held in the hands of the Emperor across the Sea? You should know all this, and at the very least the Magic, with which the Emperor created Narnia.

The changes made by Ostrovskaya are in keeping with her general tendency to reformulate the original text, possibly with the aim of bringing it closer to the target reader. Lyakhova, in contrast, opts for a closer translation, perhaps lacking the courage to make too many changes. The same is true of Aslan's explanation of his resurrection. The original refers to a magic deeper than that of the Deep Magic, and to the stillness and darkness before Time dawned. Aslan explains to the children that if the Witch had known that magic, she would have known that the Table would crack and "Death itself would start working backwards." (148) Ostrovskaya simplifies and clarifies these concepts. There is no reference to a deeper magic, (indeed, the Deep Magic is translated as the "Secret Magic" - Tainaya Magiya - where "secret" is not an adjective of degree). Here, Aslan suggests that the Witch could have looked further back to "before the history of Narnia began," and would have known that the Table would crack and "sama smert' otstupit pered nim" (death itself would retreat before it) (103). Lyakhova's translation is closer to the original text, referring to Magiya Sverkhsokrovennaya (extrahidden, or super-hidden magic) and to "tuda, gde byli lish' tishina i predrassvetnaya t'ma" (there, where there was only silence and pre-dawn darkness) (243).

In terms of general style, there is little doubt of the superiority of Ostrovskaya's translation, despite the occasional shifts and omissions. It is a translation that has clearly succeeded in reaching a wide audience of both children and parents, and has been used as a means of reinforcing Christian beliefs. Indeed, Lewis himself stated that one of his aims was to present Aslan as a possible Christ-figure in a world of talking animals, with the aim of bringing young readers closer to the figure of Christ in their own world (Hooper 1996: 425). Although the Christian allusions are assumed to be recognisable by Russian readers, both translations include glossaries explaining the references to Greek and other mythology (1999: 474-5; 1992: 411412). While source language readers are unlikely to understand all these references, there is no glossary in the original version.

Harry Potter is a very different phenomenon, which also illustrates significant changes in translation practice during the 1990s. The work is a fantasy combined with a traditional English boarding-school story. Russia was the thirty-sixth country to publish an official translation of Harry and the Philosopher's Stone in December 2000, just over three years after the publication of the original (D'yakova, 2000). ${ }^{7}$ This translation, by Oranskii, was chosen in a competition run by the publishers, "Rosmen." Russian readers, however, were impatient for the published translation, and several translations had already appeared on Russian websites devoted to Harry Potter. The translations on harrypotter.internetmagazin.ru give only the first names of the translators, generally a different person for each chapter. Another site, harrypotter.ru has a translation by M. Spivak, with the copyright held by Lingvisticheskye Komp'yuternye Sistemy, dated 2000.

As mentioned above, Russian children's literature had a specific role as a pedagogic tool during the Soviet era, and works which did not conform to Soviet ideology remained untranslated until recently. One notable example is that of Frank Baum's The Wizard of $\mathrm{Oz}$ (1899), a translation of which was prohibited by the Soviet 
censor. Volkov, the translator, then wrote an adaptation of the novel, which developed into a series of highly successful independent books. This series has been described by Soviet critics as promoting positive values such as "courage, strength, resourcefulness, kindness, loyalty and humour (Khristenko 1991: 121), which assist the characters in overcoming evil forces. As these bear a striking similarity to the values promoted in Rowling's work, the amount of criticism that the latter has provoked is surprising. Some of this criticism predictably stems from a religious worldview, which regards the work as anti-Christian. For example, one article attributed to Gleb Shul'pyakov (almost certainly a pseudonym) (2000) describes Rowling's works as superficial, and attempting to advocate an alternative and undesirable version of religious history.

Other criticism is directed at the platitudes and clichés present in the works. The values promoted in the work are implicit and assumed to be shared by the implied reader, who clearly belongs to an English cultural background. Elena D'yakova asks the question What, in the end, does it [Harry Potter] teach our young people?" (2000). She lists qualities such as: courage, decency, charity, defence of the weak, defence of the ridiculous and the laughable, a love of books, and a love for one's teachers and class-mates. She sees Harry Potter as a classic English moralistic tale, set against a backdrop of Dickensian Christmas feasts and the magical shops of London, heavily peppered with the "eccentric humour" which she states is characteristic of all Genuine English Tales" (her capitalisation). Seeking to place the stories within the framework of Soviet Russian children's literature, Petr Aleshkovskii goes so far as to conclude that Harry Potter and his friends resemble Timur's team of pioneers. The only real difference, he suggests, is that instead of catching spies trying to steal the "military plan," the protagonists are catching magical evil-doers, attempting to take the philosopher's stone (Aleshkovskii, 2000). Although Rowling may not appreciate the analogy, one could imagine a whole movement of would-be wizards seeking out traitors and turncoats. Unfortunately, outside the novel, the magic might not always work.

Alena Solntseva (2000) also points to the lack of original ideas in the book, again listing the obvious messages that friendship is paramount, telling tales is bad, and although evil is eternal, good can keep it at bay. Another critic, writing in the respected Literaturnaya Gazeta, criticises the work for merely providing a focus for numerous sub-themes containing the "moralising which is traditional in the English world-view" (Galina, 2001), a surprising comment given the strongly didactic content of much Russian children's literature during the Soviet period. Harry Potter succeeds with the help of "parental love, friendship, talent, healthy initiative, heredity and a firm understanding of fair play," which are described as the healthy values of Western civilisation. Galina does not regard the strong cultural content of the work as any impediment to readers' enjoyment, although: "Ancient castles with ghosts, catchers on brooms and cosy villages with pubs selling magic beer - this is really only possible in England."

How do translators deal with the marked cultural content of the work? As in The Lion, the Witch and the Wardrobe, food plays a significant role in Harry Potter and the Philosopher's Stone. Deprivation of food is a symbol of Harry's life with the Dursleys, just as abundance of food is a symbol of his life at Hogwarts. This is made clear at the start-of-term banquet, when the table is laden with his favourite foods: "roast beef, 
roast chicken, pork chops and lamb chops, sausages, bacon and steak, boiled potatoes, roast potatoes, chips, Yorkshire pudding, peas, carrots, gravy, ketchup and, for some strange reason, mint humbugs" (92). Each translator retains these foods with only minor variations. All give a transliteration of "Yorkshire pudding" although it is probable that a Russian child would assume it to be a sweet pudding. Traditional festivals give Rowling a further opportunity to highlight the strong cultural significance of food, although she does not refer to the underlying reasons for the celebration of Halloween or Christmas. The latter gives rise to the most lavish description of food (149-150) in which each of the three translations examined adopts slightly different strategies (Evgeniya [TT1], Spivak [TT2] and Oranskii [TT3]).

Christmas dinner in an English culture contains certain compulsory elements. It includes turkey, roast potatoes, several different vegetables, and cranberry sauce, and is almost invariably followed by Christmas pudding - traditionally made with a coin hidden inside which brings luck to the person who finds it. In addition it is normally drenched with brandy and set alight just before serving. Christmas at Hogwarts lives up to the tradition:

Harry had never in all his life had such a Christmas dinner. A hundred fat, roast turkeys, mountains of roast and boiled potatoes, platters of fat chipolatas, tureens of buttered peas, silver boats of thick, rich gravy and cranberry sauce - and stacks of wizard crackers every few feet along the table... Flaming Christmas puddings followed the turkey. Percy nearly broke his teeth on a silver Sickle embedded in his slice. (150)

Although the events are clearly taking place in Britain, one might expect some adaptation of specifically British foods, even though there is no equivalent of "Christmas dinner" in Russia. The two earlier translations retain the items offered in the original; this results in occasional problems involving lexical gaps in the target language. Christmas pudding is translated as rozhdestvenskii puding in all three translations - a pudding which would activate a rather fuzzy image in the mind of the Russian reader. TT2 describes the pudding covered in "flaming punch," while TT1 describes it simply as "flaming." Oranskii's version of the passage reflects a greater number of shifts. It is worth quoting the extract in

\author{
У Гарри в хизни не было такого рождественского пира. На столе \\ красовались сотни жирных жареных индеек, горы жареного и \\ вареного картофеля, десятки мисок с жареным зеленым \\ горошком и соусников, полных мясной подливки и
}

клюкженного варенья, и башни из волшебных хлопушек...

Вслед за индейкой подали утыканные свечками рождественские

пудинги. (253)

Harry had never had such a Christmas feast in his life. On the table were hundreds of fat roast turkeys, mountains of roast and boiled potatoes, dozens of bowls of roast green peas and boats full of meat sauce and cranberry preserve, and mounds of magic crackers... After the turkey came Christmas puddings dotted with candles. 
It is difficult to account for the transformation of Christmas puddings into birthday cakes. Such a rendering may confuse and mislead Russian readers, although Christmas does after all celebrate a birthday. Moreover, the reference to roast green peas is unlikely, although it is possible that canned green peas may be heated in an oven.

Christmas crackers, another traditional accompaniment, are either rendered using a loan word, "kreker," (TT2) or by the Russian functional equivalent "khlopuski" (TT1 and TT3). While Percy nearly breaks his teeth on a silver Sickle - a coin in the magic world - Evgeniya's Percy almost suffers the same fate on a silver horseshoe (while the translator of the fifth chapter uses the loan-word, "sikl"for the coin). Spivak and Oranskii both use the loan-word sikl in both cases. Although there is a Russian word for sickle - serp, this is not used, perhaps because of its strong cultural significance as an emblem of the Soviet regime.

Later that afternoon, exhausted after a snowfight, the friends return to the house common room, translated by gostinaya (sitting-room) (TT1 and TT2), or by komnata otdykha (leisure room) by Oranskii, for "tea." The fare in the original consists of turkey sandwiches, crumpets, trifle and Christmas cake. All the translators include turkey sandwiches, but Spivak adds items such as "fancy biscuits, truffles, and Christmas pie (pirog), while Evgeniya has her protagonists eating doughnuts, sponge cakes and Christmas pie (pirog). Oranskii's translation illustrates a stronger intervention in the text. Apparently assuming that it would be impossible to eat "tea" after such a huge Christmas dinner, he moves both the snowfight and "tea" to the following day. The children are then deemed hungry enough to eat turkey sandwiches, buns, sponge cakes and Christmas pie (pirog).

Food is one of the most significant elements in the work, but equally significant are the names given to various characters. None of the translations succeeds in transferring the associative meaning of these names. The highly important name given to "ordinary people" - Muggles - has connotations in English of stupidity (a real "mug") or plainness (what an ugly mug!). To transliterate this name as Magly could imply that the root is mag, although this is not immediately obvious in Russian. Spivak chooses "Mugly," which remains fuzzy in Russian. The Dursleys live in "Privet Drive," strongly symbolic of English suburbia, which is characterised by numerous privet hedges. TT18 and TT3 transliterate the name as praivet instead of privet, (the latter being Russian for "hello"). TT2 (Spivak) translates the name, using the botanically correct Russian "biryuchinovaya alleya" (Privet Avenue). It is interesting to note that the translator of the second Harry Potter book, M.D. Litvinova, changes the street name to "Tisovaya Ulitsa" (Yew Street).

The names of the four houses at Hogwarts are also significant. First, the word "house" itself represents a lexical gap in Russian, where the English boarding-school house system is not familiar. TT1 and TT2 both use the loan-word kolledzh, defined in the dictionary as "the name of certain boarding schools abroad" (Ozhegov 1987:244). Oranskii selects fakul'tet, which has the same meaning as the English "faculty" in a tertiary institution. Neither signifies the importance of the house to which one belongs, and to which one owes considerable loyalty, reflected in the importance attached to the winning of the House Cup. The names of the houses, Gryffindor, Hufflepuff, Ravenclaw and Slytherin, are transliterated into Russian with no attempt to transfer the associative meaning (the last is variously rendered as Sliterin in TT1, Slizerin in TT2 and Slaizerin in TT3, as there is no "th" sound in Russian). Again, the 
translator of the second Harry Potter book uses a different strategy, choosing to rename Hufflepuff and Ravenclaw as Puffendui, and Kogtevran (derived from kogot' or 'claw').

Similar strategies can be found in the transfer of the names of the teachers and the ghosts at Hogwarts. Oranskii opts for the straightforward transliteration of all the names, while Spivak randomly provides alternatives. For example, Peeves the poltergeist remains Pivz in TT1 and TT3, but becomes Dryuzg in TT2. Similarly, Professor Sprout, who teaches herbology, remains Spraut in TT3, but is transformed to Sparzhella in TT2, a name derived from sparzha (asparagus), and is translated directly by Rostok in TT1. Other teachers, such as Flitwick, McGonagall, Binns, Quirrel, and Snape, are transliterated in both TT1 and TT3, but Snape and Quirrel are given alternative names in TT2 - Zlei, which is derived from zlo (harm, evil), and Belka (squirrel). Litvinova, in the second book, is more inventive in her choice of names. She turns Snape into Snegg, related to sneg (snow) and Sprout into Stebl,' from stebel' (stem or stalk).

One of the strongest cultural elements not directly related to lexical items is the “eccentric humour" described by D'yakova (2000). The humorous episodes in the work are transferred directly by the translators, although it is not certain that they would always be understood by the target text reader. The fact that much of the very wry humour was omitted in the film version of the book confirms that different cultures express humour differently. Many comments in the dialogue are ironic or sarcastic understatements typical of English humour, and often unrecognised in other cultures.

This article attempted to examine certain strategies used by translators of two English fantasy stories, both of which are firmly rooted in an English landscape and in English culture. The analysis shows that the approach to translation is largely random, with no consistent strategies identifiable. In the translations of The Lion, the Witch and the Wardrobe, there is some evidence of simplification as a strategy, and some confusion over the appropriate translation of cultural items in the translations of Harry Potter and the Philosopher's Stone. Generally, however, the translators are shown not to have attempted to situate the stories in a Russian context, and have retained intact both the cultural backdrop and the moral values put forward in the works. Such an approach to the translation of these texts therefore depends on extensive background knowledge on the part of the target text reader. The translators expect their readers to share the knowledge that both the implied and actual source text reader are assumed to possess. The target text readers then have to bridge the gap between themselves and the source text readers, if the work is to have the same effect and arouse the same associations. Given the current increasing access to the internet, it may be that contemporary readers are assumed to possess a wider knowledge than their predecessors. Whether or not that is true, there is little doubt that the translation of such works contributes to the spread of English culture and values across the world. While it was not possible in his article to focus on the reception of such works by young readers, such a study would provide valuable information about the success or failure of the translations discussed above. 


\section{NOTES}

1. Incidentally, his translation, which appeared in 1974, is called a pereskazka or retelling, rather than a perevod or translation.

2. I am using the term "fantasy" in its broadest sense, to include works that have strong elements of the fantastic in them. I am aware that Alice in Wonderland is not considered a fantasy by many writers.

3. Peter Pan first appeared in Russian translation in 1918, with newer translations in 1968 and 1987. Mary Poppins first appeared in 1934 with several reprints and a new translation in 1992.

4. For a detailed discussion by a Russian author on foreign literature in Russian translation up until the 1990s, see Brandis, Ye., (1990) Ot Ezopa do Dzhanni Rodari: zarubezhnaya literature $v$ detskom $i$ iunosheskom chtenie, Moskva, Detskaya Literatura.

5. A simple search on yandex for "Narnia" yields 3,495 hits, while a search on AltaVista for English language sites resulted in 5,900 hits, indicating that the number of Russian sites is comparatively high.

6. These are back-translations of the Russian passages in order $\mathrm{d}$ to reflect the content and structure of the Russian translations.

7. By official translation, I mean the one which was approved by Rowling and which complied with copyright law, unlike the unofficial internet versions which appeared first. There has since been another published translation, and the three subsequent books have also been published in Russian, but with different translators. I do not have a copy of the second translation of the first book at present.

8. It should be noted that each chapter on this website appears to have been translated by a different person, and the name is not always provided.

\section{REFERENCES}

Aleshkovskiı, P., (2000): “Volshebstvo bez razoblacheniya," Parad Planet, <http://rusf.ru/ko/ parad/010316_3.htm>.

Aspatore, J.V. (1989): The Military-Patriotic Theme in Soviet Textbooks and Children's Literature, Ph.D. thesis, University of Georgetown, UMI Dissertation Service.

D’ıакоva, E. (2000): (Untitled), www.gazeta.ru, 18.12.2000.

Dixon, B. (1977): Catching Them Young (Volume 1), London, Pluto Press.

Dixon, B. (1978): Catching Them Young (Volume 2), London, Pluto Press.

GAlinA, M. (2001): “Zhorik Gorshkov i ego tovarishchi," Literaturnaya gazeta, (3-5818), 17 23.01.2001.

Hooper, W. (1996): C.S.Lewis: A Companion and Guide. London, HarperCollins.

Khristenko, M.A., (1991): “Puteshestvie v volshevnuyustranu,” Literatura v shkole, (2), pp. 121125.

Kuraev, A. (2001): “Zakon bozhi i khroniki Narniya," Shkol'noe bogoslovie, <http://www.kuraev. $\mathrm{ru} / \mathrm{scool}$.html>.

Lewis, C.S. 1976 (1950): The Lion, the Witch and the Wardrobe, Harmondsworth, Puffin Books.

Lewis, C. S. (1992): Narniya, (tr. L. Lyakhova), Izhevsk, RIO: "Kvest."

Lewis, C.S. (1999): "Lev, koldun'ya i platyanoi shkaf," (tr. G. Ostrovskaya), Clive Staples Lewis, Volume 8, Moskva, Bibliya dlya vsekh, pp. 9-118.

Nikolajeva, M. (1996): Children's Literature Comes of Age: Toward a New Aesthetic, New York and London, Garland Publishing.

Nikolajeva, M. (2000): From Mythic to Linear: Time in Children's Literature, London, Scarecrow Press.

Ozhegov, S.I., (1987): Slovar' russkogo yazyka, Moskva, Russkii Yazyk.

Rowling, J.K. (1997): Harry Potter and the Philosopher's Stone, London, Bloomsbury Publishing. Rowling, Dzh.K. (2001): Garri Potter i filosofskoi kamen,' (tr. I.V. Oranskii), Moskva, Rosmen.

Rowling, Dzh.K. (2000): Garri Potter i filosofskoi kamen,' (tr. M. Spivak), Lingvisticheskie Komp'iuternye Sistemy, <http://www.harrypotter.ru>.

Rowling, Dzh.K. (2000): Garri Potter i filosofskoi kamen,'<http://www.harrypotter.internet magazin.ru>. 
Rowling, Dzh. K. (2001): Garri Potter i tainaya komnata, (tr. M.D.Litvinova), Moskva, Rosmen. Shavit, Z. (1986): Poetics of Children's Literature, Georgia, University of Georgia Press.

Shneidman, N.N. (1973): Literature and Ideology in Soviet Education, Toronto, University of Toronto.

Shul'Piakov, G. (2000): “Razbiraya Garri," Nenavisimaya Gazeta, 14.12.2000.

Solntseva, A. (2000): (Untitled), Vremya, 2000, <http://www.vremya.ru/2000/188/7/5300. html>.

Sutherland, R.S., (1985): "Hidden Persuaders: Political Ideologies in Literature for Children," Children's Literature in Education, 16-3, pp. 143-157.

Vol’Pe, M. (1989): “Stoit li zabyvat' Penroda?,” Detskaya Literatura, (8), pp.42-45. 